\title{
Sagebrush Response to Conifer Cover
}

\author{
Karen A. Kitchen \\ Dept. of Animal \& Range Sciences, Montana State University \\ PO Box 172900, Bozeman, MT 59717-2900 \\ E-mail: karen.kitchen@msu.montana.edu \\ Brittany Goldsmith \\ Dept. of Animal \& Range Sciences, Montana State University \\ PO Box 172900, Bozeman, MT 59717-2900 \\ E-mail: bmendelsohn2@gmail.com \\ Jim Robison-Cox \\ Dept. of Mathematical Sciences Sciences, Montana State University \\ PO Box 172400, Bozeman, MT 59717-2400 \\ E-mail: jimrc@math.montana.edu \\ Michael Frisina \\ Dept. of Animal \& Range Sciences, Montana State University \\ PO Box 172900, Bozeman, MT 59717-2900 \\ E-mail: mfrisina@bresnan.net \\ Bok Sowell (Corresponding author) \\ Dept. of Animal \& Range Sciences, Montana State University \\ PO Box 172900, Bozeman, MT 59717-2900 \\ Tel: 1-406-994-5558 E-mail: bok@montana.edu
}

Received: October 15, 2015 Accepted: November 6, 2015

doi:10.5296/emsd.v5i1.8665 URL: http://dx.doi.org/10.5296/emsd.v5i1.8665 


\begin{abstract}
Sagebrush habitat is declining throughout the United States. This can have negative impacts for big game as well as other wildlife species. The purpose of our research was to analyze the relationship between several abiotic factors and the cover of two conifer species, Douglas-fir (Pseudotsuga menziesii) and Rocky Mountain juniper (Juniperus scopulorum), on the cover of Wyoming (Artemisia tridentata spp. wyomingensis) and mountain (Artemisia tridentata spp. Vaseyana) big sagebrush. Abiotic factors, percent cover of sagebrush and conifers, and individual conifer age and canopy area were recorded at 40 Wyoming and 40 mountain big sagebrush plots at each of three study sites in southwest Montana $(n=240)$. No correlation was found between any abiotic factor and live sagebrush cover over all sites ( $p>0.05)$. A model of the relationship between the combined cover of the two conifer species and the two subspecies of big sagebrush was developed. The best-fit model included the terms: study site, sagebrush subspecies, $\sqrt{\text { conifer cover }}$ and the interaction, study site by sagebrush subspecies as the independent variables, with $\sqrt{\text { sagebrush cover }}$ as the dependent variable $(\sqrt{\text { sagebrush cover }}=$ Intercept $\left.\mathrm{t}_{\mathrm{i}}-0.401 \sqrt{\text { conifer cover }} ; \mathrm{R}^{2}=0.61\right)$. There was a negative relationship between conifer cover and sagebrush cover and no difference in the effects of conifer cover on the two sagebrush subspecies. Validation trials were successful at one of three locations outside the study area and suggested that the model is better suited to lower elevation, less productive sites. Individual Douglas-fir have a 3 fold larger canopy area than Rocky Mountain juniper at comparable ages $(\mathrm{p}<0.001)$. Controlling conifers to increase Wyoming big sagebrush does not appear to be effective due to the low level of sagebrush cover. If conifer control is desired, Douglas-fir should be targeted over Rocky Mountain juniper on mountain big sagebrush sites, but not on Wyoming big sagebrush sites.
\end{abstract}

Keywords: Sagebrush, Juniper, Douglas-Fir

\title{
1. Introduction
}

Sagebrush steppe is among the most endangered ecosystems in the United States (Noss, LaRoe \& Scott, 1995). Approximately 50 percent of historical sagebrush habitat has been permanently altered by agriculture, urbanization, plowing, chaining, reseeding, fire (both prescribed and wild), and other human developments (Harrington, 2002; Welch, 2005). Much of the remaining sagebrush habitat has been fragmented by roads, pipelines, powerlines and natural resource development, which provide corridors for invasion by exotic species (Knick et al., 2003). Sagebrush steppe is also being altered by the expansion of conifers. Although the range of conifers has been expanding and contracting throughout the west over the past 12,000 years in response to climatic changes, the current rate of conifer expansion is unprecedented (Miller \& Wigand, 1994). Not only does climate have an impact, but increased grazing and reduced fire frequencies during the past 150 years are considered likely causes of conifer expansion (Arno \& Gruell, 1983; Miller \& Rose, 1999).

Regardless of the causes of increased expansion, conifer cover can impact plant species composition and therefore habitat within the forest/sagebrush ecotone. This ecotone is particularly important winter range for elk (Cervus elaphus) and mule deer (Odocoileus hemionus) because it provides both food and cover (Knight, 1994). Big sagebrush (Artemisia tridentata) and juniper (Juniperus spp.) are major components of the winter diet of mule deer (Hansen \& Reid, 1975; MacCracken \& Hansen, 1981). Rocky Mountain juniper (Juniperus 
scopulorum) is considered a valuable winter browse species for elk as well (Kufeld, 1973), while big sagebrush can comprise 5 to 20 percent of the winter diets of both elk (Kufeld, Wallmo \& Feddema, 1973) and Rocky Mountain big horn sheep (Ovis Canadensis; Keating, Irby and Kasworm, 1985). However, as conifers increase in density and range at the forest edge, they reduce sagebrush cover (Miller, Svejcar \& Rose, 2000; Grove, Wambolt \& Frisina, 2005, Coultrap et al., 2008). This has been an increasing management concern as overall sagebrush habitat continues to decrease.

Since 1860 the estimated area occupied by juniper or pinyon species (Pinus spp. L.) has increased 140 to 625 percent in the central and northern Great Basin (Miller, Tausch, McArthur, Johnson \& Sanderson, 2008), and expansion of western juniper (Juniperus occidentalis Hook.) has been recorded at rates as high as 4.5 percent $\mathrm{yr}^{-1}$ in southwest Idaho (Strand et al., 2006). Many studies of conifer expansion focus on western juniper (Belsky, 1996). Rates of expansion can be variable by location and species. Much of our current knowledge of conifer expansion focuses on western juniper which can form dense, closed canopy stands (Gedney, Azuma, Bolsinger \& McKay, 1999). However, there is little information on the ecology of expanding Rocky Mountain junipers which grow exclusively in open park-like stands (Klinka, Worrall, Skoda \& Varga, 2000) or in association with other tree species (Sudworth, 1915).

Natural resource agencies currently control conifers within the forest/shrub steppe ecotone in order to maintain or improve forage for domestic livestock and wildlife, and maintain diverse, healthy and dynamically stable ecosystems (United States Department of Agriculture [USDA], 1987; Bureau of Land Management [BLM], 1997). However, an incomplete picture exists of the interaction between the combined conifer cover of Rocky Mountain juniper and Douglas-fir and sagebrush cover. Despite this lack of information, land management agencies are treating Rocky Mountain juniper and Douglas-fir through burning and/or cutting to increase sagebrush habitat (Helena National Forest, 2008). Currently juniper is more likely to be treated than Douglas-fir even though Douglas-fir grows faster (Sherich, Pocewitz \& Morgan, 2007; USDA Natural Resource Conservation Service [NRCS], 2010a).

Our study examines the effect of abiotic factors as well as the impacts of conifer cover on sagebrush cover by considering the combined effects of Rocky Mountain juniper and Douglas-fir on the cover of mountain and Wyoming big sagebrush. The objectives of our study were to: (1) determine if abiotic factors, including: aspect, slope elevation, soil texture, soil depth, and percent rock outcroppings are correlated with sagebrush cover; (2) build a best-fit model to predict the effects of Rocky Mountain juniper and Douglas-fir cover on mountain and Wyoming big sagebrush cover; (3) determine if conifer cover affects the cover of Wyoming and mountain big sagebrush differently, and; (4) compare the canopy areas of similarly aged Rocky Mountain juniper and Douglas-fir, and determine whether either species has a greater influence on sagebrush cover. Understanding these ecological relationships can help land managers predict the outcome of controlling Rocky Mountain juniper and/or Douglas fir.

\section{Materials and Methods}

\subsection{Study Area Description}

The three study areas in southwestern Montana are situated on the foothills and mountain slopes of the northern Rocky Mountains east of the Continental Divide (Figure 1). These areas were selected because they have varying densities of Rocky Mountain juniper and Douglas-fir grading 
into communities of Wyoming big sagebrush and mountain big sagebrush within the forest/shrub steppe ecotone. Climate is similar in all three study areas and consists of a continental weather pattern with cold, dry winters, warm summers and the majority of precipitation occurring between May and September, with June having the highest precipitation. Annual precipitation at the closest weather stations, Townsend, Whitehall and Boulder, MT, averages 27, 26 and $28 \mathrm{~cm}$, respectively (WRCC, 2010).

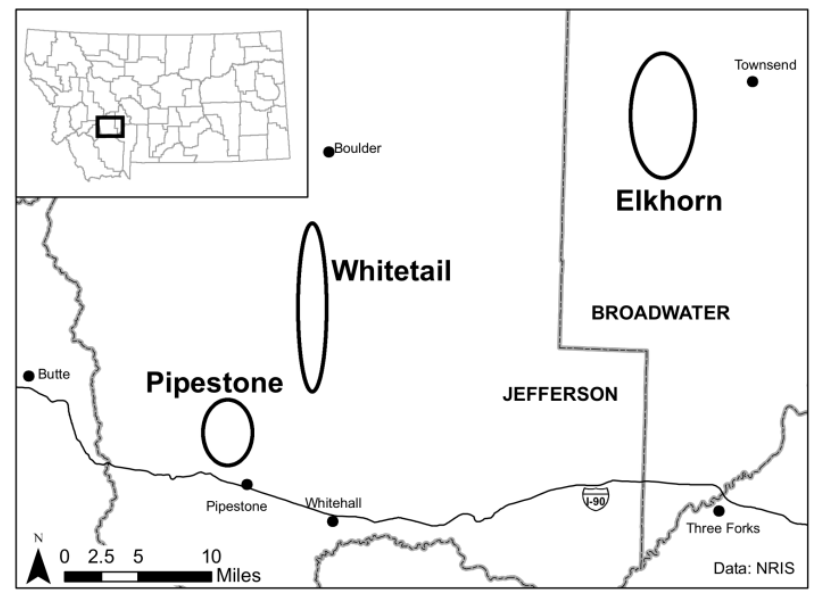

Figure 1. Map of the Elkhorn, Pipestone and Whitetail study sites in Jefferson and Broadwater counties, Montana.

The Pipestone study area is located approximately $8 \mathrm{~km}$ north of Pipestone, MT. Latitude and longitude ranges from $45^{\circ} 56^{\prime} \mathrm{N}$ to $46^{\circ} 00^{\prime} \mathrm{N}$ and $112^{\circ} 14^{\prime} \mathrm{W}$ to $112^{\circ} 18^{\prime} \mathrm{W}$ and plot elevations were between 1538 to $1817 \mathrm{~m}$. The Whitetail study area is located on the west side of the Whitetail Basin from approximately $16 \mathrm{~km}$ north of Whitehall, MT to $8 \mathrm{~km}$ south of Boulder, MT $\left(46^{\circ} 02^{\prime} \mathrm{N}\right.$ to $46^{\circ} 11^{\prime} \mathrm{N}$ and $112^{\circ} 06^{\prime} \mathrm{W}$ to $\left.112^{\circ} 10^{\prime} \mathrm{W}\right)$, with elevations ranging from 1582 to $1754 \mathrm{~m}$. The Elkhorn study area is located on the eastern flank of the Elkhorn Mountains approximately $10-15 \mathrm{~km}$ west and southwest of Townsend, MT $\left(46^{\circ} 14^{\prime} \mathrm{N}\right.$ to $46^{\circ} 21^{\prime} \mathrm{N}$ and $111^{\circ} 38^{\prime} \mathrm{W}$ to $111^{\circ} 43^{\prime} \mathrm{W}$ ), elevations between 1456 and $1889 \mathrm{~m}$.

Pipestone and Whitetail study areas are located on the southern and eastern edges of the Boulder Batholith, respectively. Parent material consists of intrusive igneous rock (Montagne, Munn, Nielsen, Rogers \& Hunter, 1982) formed during the Cretaceous period (Smedes, Klepper \& Tilling, 1968). Rock outcroppings of granite, mainly in the form of quartz monzonite and granodiorite are common. Parent material in the Elkorn area is classified as colluvium and residuum from igneous rock or hard shale and sandstone (USDA NRCS, 2010b) derived from Paleozioc sedimentary rocks, Mesozoic sedimentary rocks, and upper Cretaceous volcanic rocks (Klepper, Ruppel \& Freeman, 1971). Habitat types, based on Mueggler and Stewart (1980), include: Artemisia tridentata/Agropyron spicatum (MONT) h.t. (big sagebrush/bluebunch wheatgrass) and Artemisia tridentata/Festuca idahoensis (MONT)h.t. (big sagebrush/Idaho fescue), at all three study areas, and Artemisia tridentata/Festuca scabrella h.t. (big sagebrush/rough fescue) at the Elkhorn study area. 


\subsection{Field Methods}

Data was collected at six sites (one Wyoming and one mountain big sagebrush site at each of the three study areas. Forty plots within each site $(n=240)$ were selected to represent the entire range of conifer canopy cover. Abiotic factors were collected for each plot. Slope was measured with a Häglof electronic clinometer. Aspect was measured with a compass and assigned one of 16 directions. Elevation was determined with a Garmin GPS V at the southeast corner of each plot. Soil depth was measured with a probe from the soil surface to solum at each plot (Montagne, 2009). Soil texture was determined through hand texturing. Percent rock outcropping was estimated ocularly.

The $30 \times 30 \mathrm{~m}$ plots contained three $30 \mathrm{~m}$ line transects oriented from south to north and beginning at 5, 15 and 25 meters along the southern baseline. Canopy cover of each conifer and both big sagebrush subspecies was collected along the three transects and totaled for each plot using the line intercept method (Canfield, 1941). Gaps in canopy greater than $3 \mathrm{~cm}$ were not included in cover measurements (Wambolt, M. Frisina, Knapp \& R. Frisina, 2006).

Canopy area was measured for 3,740 Douglas-fir and 4,623 Rocky Mountain junipers by measuring the canopy radius of each tree and using the equation $A=\pi r^{2}$ since canopies were essentially circular. Douglas-fir were placed into one of four classes based on diameter at breast height $(\mathrm{DBH})$ : seedlings $(<1 \mathrm{~m}$ tall), saplings $(<15 \mathrm{~cm} \mathrm{DBH})$, pole $(15-30 \mathrm{~cm} \mathrm{DBH})$ and mature (>30cm DBH; Arno \& Gruell, 1986). Rocky Mountain junipers were placed into classes based on basal trunk diameters (BTD) measured at ground level near the root collar (Mueller et al., 2005). The three classes for juniper were: seedling ( $<3 \mathrm{~cm}$ BTD), juvenile (3-12cm BTD) and mature (>12cm BTD; Chojnacky, 1997). Conifer age was estimated by cutting or coring and counting tree rings of 210 Douglas-fir and 199 Rocky Mountain juniper (approximately 10 trees within each age class from each site (Sindelar, 1971).

\subsection{Data Analysis}

Plots with less than $2 \%$ conifer cover were compared with a t-test to determine whether there was a difference between mean live sagebrush cover of Wyoming and mountain big sagebrush when the impact of conifer cover was minimal using PROC TTEST in SAS ${ }^{\circledR}$ 9.2. Only live sagebrush cover was used in all analyses although both live and dead conifer cover was used, since it was assumed that dead conifers had recently impacted sagebrush cover. The significance level for all analyses was set at $\mathrm{p} \leq 0.05$.

Correlations between the individual abiotic factors (slope, aspect, elevation, soil depth, soil texture, and percent rock) and big sagebrush cover were evaluated using multiple linear regression analysis. This analysis was run for all sites combined and each individual site.

A model of the relationship between percent conifer cover (independent variable) and percent live sagebrush cover (dependent variable) was developed using an information criterion (AIC; Akaike, 1974). An AIC is a measure of goodness of fit of an estimated statistical model, and is a tool used for model selection. It provides a measure of the information lost when a particular model is used to describe a relationship, and compares the trade-off between simplifying the model and still maintaining an adequate representation of the data (Burnham \& Anderson, 2002). If removing an interaction from the model reduced the AIC, then that interaction was left out of the reduced model. Since the variance of live sagebrush cover increased as mean live sagebrush 
cover increased, the square root transformation within the family of Box-Cox power transformations was selected in $\mathrm{R}^{\circledR}$ for all cover values before the model was developed. A full model for all sites was built using main effects for study area $(n=3)$, sagebrush subspecies $(n=2)$ and conifer cover. The interactions within the full model included: study area by sagebrush subspecies; study area by conifer cover; sagebrush subspecies by conifer cover; and, study area by sagebrush subspecies by conifer cover. Removal of interactions from the model was supported by analysis of F-tests. In addition, F-tests were used to see if the reduced model maintained similar slopes across the three study areas and for both sagebrush subspecies. Finally, the $95 \%$ confidence intervals for the slope of the relationship at all six sites were reviewed.

Internal validation of the reduced model was accomplished by withholding the 40 data points generated from one site. The model of the remaining 200 data points from the other five sites was examined to see how well it predicted the slope of the withheld points. This process was repeated six times with the 40 data points from each of the different sites withheld each time. External validation of the model was conducted by using all 240 points from data collected in this study to predict the slope of the regression line of the conifer/sagebrush data collected by Grove (1998) at three other sites in southwest Montana. The Grove sites contained Douglas-fir as the conifer and mountain big sagebrush as the understory shrub. The $95 \%$ confidence interval of the slope of the reduced model was compared to the $95 \%$ confidence interval of the slope for each of the three Grove sites.

The reduced model was used to test the difference between the influence of Rocky Mountain juniper or Douglas-fir canopy cover on the cover of live sagebrush. Each conifer species was added back into the model to see whether the addition of either increased the AIC, and F-tests were also analyzed to determine if differences were observed in live sagebrush cover when adding each species of conifer back into the reduced model.

Evaluation of the difference in canopy area of Douglas-fir and Rocky Mountain juniper was completed in four phases using Excel 12.0. Phase one involved constructing a simple linear regression between age and DBH for Douglas-fir or BTD for Rocky Mountain juniper. In phase two, a simple linear regression was constructed between canopy area and the correlating DBH or BTD. Phase three used the equations developed in phase one and two to calculate an average age for every DBH or BTD measurement and then plotted canopy area relative to age to predict canopy area at each year of age. Phase four ran a paired t-test to determine if the predicted canopy area of each tree differed at comparable ages.

\section{Results}

There was no correlation between live sagebrush cover and any of the abiotic variables over all sites combined ( $\mathrm{p}>0.05$ ). Elevation, slope, aspect, and percent rock outcropping were correlated with live sagebrush cover at one or two of the sites, but soil depth and texture showed no correlation.

Conifer cover in the 240 plots ranged from 0 to $65 \%$, with 77 plots in the $0-10 \%$ conifer cover range, 81 plots with $>10-20 \%$ conifer cover, 41 plots with $>20-30 \%$ conifer cover, 21 plots with $>30-40 \%$ conifer cover, and 20 plots with $>40 \%$ conifer cover. Douglas-fir was the predominant conifer species on all three mountain big sagebrush sites (60 to $93 \%$ of total conifer cover) and slightly greater at the Pipestone Wyoming big sagebrush site (54\%), while Rocky Mountain juniper was $70 \%$ of total conifer cover at the Elkhorn and Pipestone Wyoming big 
sagebrush sites. The average Wyoming big sagebrush cover (11.74\%) and mountain big sagebrush cover $(12.8 \%)$ was not different in plots with conifer cover of less than 2 percent $(\mathrm{p}=$ 0.6898).

Three terms were removed from the full model based on AIC criteria (study area by subspecies by conifer cover, subspecies by conifer cover and study area by conifer cover). The removal of these interactions was supported by an F-test since all have p-values greater than 0.05 . Therefore, the reduced model contains the main effects of site, sagebrush subspecies and conifer cover, and only one interaction: study area by sagebrush subspecies.

Slopes of the relationship between total conifer and live sagebrush cover are not different for all sites within the model $(\mathrm{F}=2.19$ on $2,231 \mathrm{df}, \mathrm{p}=0.12)$. The $95 \%$ confidence intervals of all sites contain common values from approximately -0.40 to -0.36 . This also indicates that the slopes of the line representing the effects of square-root conifer cover on sagebrush cover are not different across the three study areas for both sagebrush subspecies (Figure 2). The model is fit for both sagebrush subspecies at all sites, so the slope (-0.40) is the same for each line with SE 0.02461. Therefore we conclude that there is no difference in the effect of conifer cover on Wyoming and mountain big sagebrush. However, the y-intercept is different for each site/sagebrush subspecies location, indicating the model predicts a slightly different level of sagebrush cover when there is no conifer cover.

$\sqrt{\text { sagebrush cover }}=$ Intercept $_{\mathrm{i}}-0.401 \sqrt{\text { conifer cover }} ; \mathrm{r}^{2}=0.61$

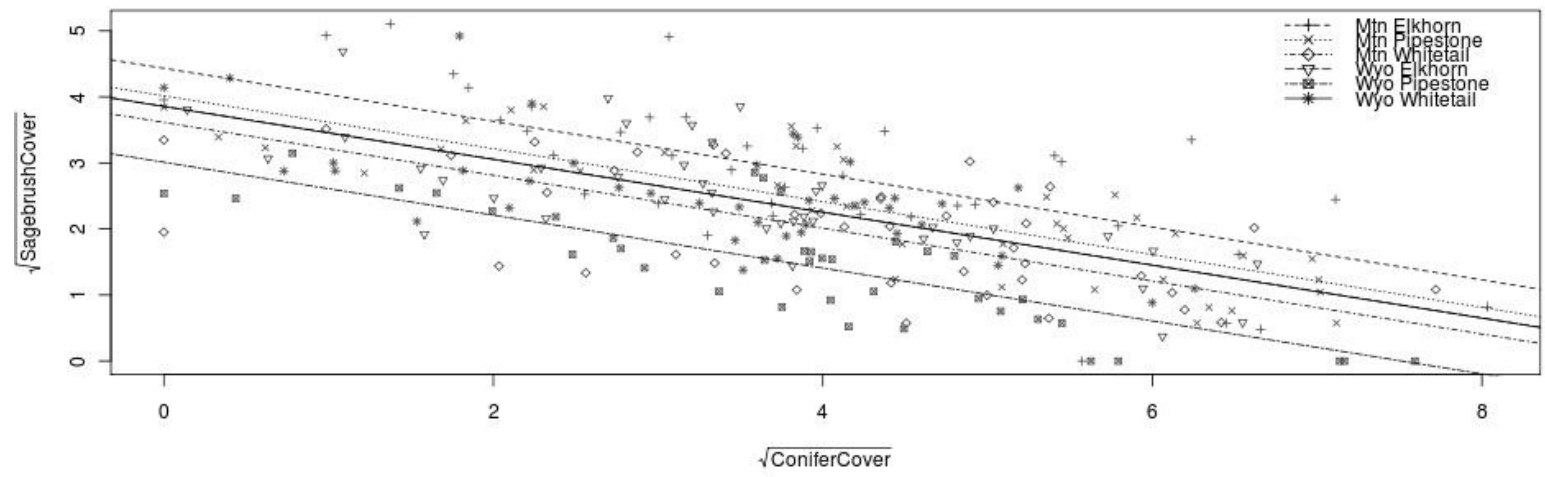

Figure 2. Slope $(-0.40)$ of the relationship of $\sqrt{\text { conifer cover }}$ and $\sqrt{\text { sagebrush cover }}$ in the reduced model for all sites. The y-intercept for each site is different $(3.86,3.01$ and 3.86 for Elkhorn, Pipestone and Whitetail Wyoming big sagebrush sites, and 4.43, 4.02 and 3.61for Elkhorn, Pipestone and Whitetail mountain big sagebrush sites).

Internal validations shows that the regression line of the 200 predictor plots falls within the $95 \%$ confidence interval of the observed plots for each of our six study sites. However, cover data from all 240 plots in this study were only able to predict the relationship between Douglas-fir cover and mountain big sagebrush cover at Grove's (1998) Sugar Loaf Mountain study site, but not at his Hells Canyon or Medicine Lodge Peak study site since the predictive lines in these two areas are not contained within the $95 \%$ confidence interval. 
The reduced model was used to test the hypothesis that there is no difference between the influence of Rocky Mountain juniper or Douglas-fir canopy cover on the cover of live sagebrush. The AIC was not increased by more than 2 points by either Douglas-fir or Rocky Mountain juniper. Additionally p-values ( 0.07 for Douglas-fir and 0.187 for Rocky Mountain juniper) show no need to add either of these variables back into the model. We concluded that the influence of conifer cover on sagebrush was similar for both conifer species.

\section{Discussion}

Simple linear regression equations for the relationship of $\mathrm{cm}$ DBH $(\mathrm{cm})$ to age (years) of Douglas-fir was $y=0.3013 x+7.8902, R^{2}=0.6108$. A paired t-test of Rocky Mountain juniper canopy area $\left(\mathrm{m}^{2}\right)$ and Douglas-fir demonstrated that these two species differ significantly $(\mathrm{P}<0.001)$ at comparable ages. Douglas-fir had a canopy area that was three times greater than Rocky Mountain juniper at similar ages.

Big sagebrush cover of $12-13 \%$ with minimal conifer cover in our study area is much lower than the generally reported cover values of $20-40 \%$ for mountain big sagebrush and $15-35 \%$ for Wyoming big sagebrush (Kitchen \& McArthur 2007). Our findings of no difference between the cover values of Wyoming and mountain big sagebrush are also unusual. Lesica, Cooper and Kudray (2007), for example, reported mean cover values of 15\% for Wyoming big sagebrush and 28\% for mountain big sagebrush in southwest Montana. Differences in sagebrush cover are indicative of the large range and heterogeneous nature of big sagebrush, and can relate to the productivity potential of the site (Goodrich \& Huber, 2001). Since the Wyoming and mountain big sagebrush communities were often adjacent to each other within our study sites, they likely had fairly similar soils and moisture regimes and therefore similar productivity potential which may explain why we found no difference in the cover values of the two subspecies.

Overall, there was no correlation between abiotic factors and live big sagebrush cover among all sites. We believe that the influence of conifer cover is greater than the relationship between any of the abiotic factors and sagebrush cover. Previous research does support a relationship between these abiotic variables and sagebrush cover (Frisina \& Wambolt, 2002). Sagebrush cover within mountain, Wyoming and black sagebrush (Artemisia nova A. Nels.) dominated sites and the topographic variables: aspect, slope, elevation and fetch, shared 66.6 percent of their variance (Burke, Reiners \& Olson, 1989). Big sagebrush has a wide range and plasticity of environmental requirements which most likely explains the inconsistency in relationships between abiotic factors and live big sagebrush cover.

Regression analysis detected a significant negative relationship between total conifer cover and live sagebrush cover in both Wyoming and mountain big sagebrush habitats. This is consistent with previous research in Oregon and Northern California in western juniper woodlands (Miller et al., 2000; Coultrap et al.; 2008, Rowland, Suring, Tausch, Greer \& Wisdom.; 2008), as well as in a Douglas-fir/sagebrush ecotone in southwest Montana (Grove et al., 2005).

Our model of total conifer cover and live sagebrush cover across all sites suggests that a large percent of the variability (61\%) found in sagebrush cover throughout the study areas can be attributed to conifer cover. The model was a good predictor of sagebrush cover at all sites, indicating that the relationship between sagebrush cover and conifer cover is similar in both Wyoming and mountain big sagebrush communities in the study area. However, even though Wyoming and mountain big sagebrush decrease at a similar rate as conifer cover increases, it is 
important to identify the subspecies of sagebrush within a management unit since the species can respond differently to management treatments. For example, both Lesica et al. (2007) and Baker (2006) estimate that recovery time following fire is much greater for Wyoming big sagebrush than mountain big sagebrush.

The predictive power of our sagebrush cover model was less accurate at locations further from our study area. Our model was able to predict sagebrush cover within the $95 \%$ confidence interval at Grove's (1998) Sugarloaf Mountain site, but prediction values for his Hells Canyon and Medicine Lodge Peak study sites fell outside of the $95 \%$ confidence interval. The two areas where our model did not predict sagebrush cover as accurately were much higher in elevation (2129-2286 m) and had higher sagebrush cover values, whereas the Sugarloaf Mountain study area fell within the elevation range of our sites and had similar sagebrush cover. Since the Hells Canyon and Medicine Lodge Peak study areas are higher in elevation they likely receive more precipitation allowing for greater productivity. This suggests that our model may have greater value at low elevation, drier and less productive sites, but limited application at higher, more mesic sites with greater productivity potential.

While the influence of Douglas-fir and Rocky Mountain juniper cover on live sagebrush cover was not found to be different in this study, Douglas-fir had a p-value close to the significance level $(\mathrm{p}=0.07)$. Possible explanations include the fact that Douglas-fir reach greater heights and therefore provide shading for longer periods during the day, or perhaps canopy density may decrease light penetration to a greater extent in Douglas-firs. Additionally, our finding that Douglas-fir has a 3 times larger canopy area than similarly aged Rocky Mountain juniper $(\mathrm{p}<0.0001)$ may indicate a greater competition for sunlight, water or other nutrients.

\section{Conclusions}

Loss of sagebrush habitat by expanding forests is a concern in many areas. Yet, we would not recommend the use of fire or cutting to control conifers in these areas, since disturbance in this important ecotone can displace wildlife for many years by removing both browse and cover. We particularly recommend minimizing control of Rocky Mountain juniper, because of its slow growth rate and cover area as compared to Douglas-fir, and its importance to wildlife. Additionally, our findings indicate that large increases in sagebrush cover should not be expected in these low elevation forest/sagebrush ecotones even with complete removal of the forest canopy, since these areas had an average of only $12 \%$ sagebrush cover even when conifer cover was less than $2 \%$.

Despite our recommendations, there may be some limited situations where increases in sagebrush are warranted. In these situations, selective cutting of mature Douglas-fir can open the canopy to make sunlight, water and nutrients available for sagebrush. Where necessary, it is best to begin control of Douglas-fir at low levels of conifer cover because sagebrush cover decreased by $50 \%$ with only $10 \%$ conifer cover.

\section{References}

Akaike, H. (1974). A new look at the statistical model identification. IEEE Transactions on Automatic Control 19, 716-723. http://dx.doi.org/10.1109/TAC.1974.1100705

Arno, S. F., \& G. E. Gruell. (1983). Fire history at the forest-grassland ecotone in southwestern Montana. Journal of Range Management, 36, 332-336. http://dx.doi.org/10.2307/3898481 
Arno, S. F., \& G. E. Gruell. (1986). Douglas-fir encroachment into mountain grasslands in Southwestern Montana. Journal of Range Management 39, 272-275. http://dx.doi.org/10.2307/3899067

Baker, W. L. (2006). Fire and restoration of sagebrush ecosystems. Wildlife Society Bulletin 34, 177-185. http://dx.doi.org/10.2193/0091-7648(2006)34[177:FAROSE]2.0.CO;2

Belsky, J. A. (1996). Viewpoint: Western juniper expansion: is it a threat to arid northwestern ecosystems? Journal of Range Management 49, 53-59. http://dx.doi.org/10.2307/4002725

Bureau of Land Management [BLM]. (1997). Environmental Assessment: Toll Mountain habitat project. Headwaters Resource Area. Bureau of Land Management. Butte, Mont. 46p.

Burke, I. C., W. A. Reiners, \& R. K. Olson. (1989). Topographic control of vegetation in a $\begin{array}{lllll}\text { mountain big sagebrush steppe. Plant ecology. 84(2), } & \text { 77-86. }\end{array}$ http://dx.doi.org/10.1007/BF00036508

Burnham, K. P., \& D. R. Anderson. (2002). Model selection and multimodel inference: a practical information-theoretic approach, $2^{\text {nd }}$ ed. New York, NY: Springer-Verlag. 488p.

Canfield, R. H. (1941). Application of the line interception method in sampling range vegetation. Journal of Forestry, 39, 388-394.

Chojnacky, D. C. (1997). Modeling diameter growth for pinyon and juniper trees in the dryland forests. Forest Ecology and Management, 93, 21-31. http://dx.doi.org/10.1016/S03781127(96)03948-5

Coultrap, D. E., K. O. Fulgham, D. L. Lancaster, J. Gustafson, D. F. Lile, \& M. R. George. (2008). Relationships between western juniper (Juniperus occidentalis) and understory vegetation. Invasive Plant Science and Management 1, 3-11. http://dx.doi.org/10.1614/IPSM-07008.1

Frisina, M. R., \& C. L. Wambolt. (2002). Montana Sagebrush Guide. Montana Department of Fish, Wildlife \& Parks.

Gedney, D. R., D. L. Azuma, C. L. Bolsinger, \& N. McKay. (1999). Western juniper in eastern Oregon. USDA For. Ser. PNW-GTR-464.

Goodrich, S., \& A. Huber. (2001). Mountain big sagebrush communities on the Bishop Conglomerate in the eastern Uinta Mountains. In: E. D. McArthur \& D. J. Fairbanks [COMPILERS] Proceedings of the $11^{\text {th }}$ Wildland Shrub Symposium: Shrubland Ecosystem Genetics and Biodiversity; 13-15 June 2000; Provo, UT. Ogden, UT: US Department of Agriculture Rocky Mountain Research Station, RMRS-P-21. 336-343.

Grove, A. J. (1998). Effects of Douglas fir establishment in southwestern Montana mountain big sagebrush communities (M.S. Thesis). Bozeman, MT: Montana State University. 150p.

Grove, A. J., C. L. Wambolt, \& M. R. Frisina. (2005). Douglas-fir's effect in mountain big sagebrush wildlife habitats. Wildlife Society Bulletin. 33, 74-80. http://dx.doi.org/10.2193/00917648(2005)33[74:DEOMBS]2.0.CO;2

Hansen, R. M., \& L. D. Reid. (1975). Diet overlap of deer, elk, and cattle in southern Colorado. Journal of Range Management, 28, 43-47. http://dx.doi.org/10.2307/3897577 
Harrington R. D. (2002). A historical perspective of Montana's sagebrush. Intermountain Journal of Sciences, 8, 61-66.

Helena National Forest. (2008). Annual Monitoring Report: Fiscal Year 2007.

Keating, K. A., L. R. Irby, \& W. F. Kasworm. (1985). Mountain sheep winter food habits in the upper Yellowstone Valley. Journal of Wildlife Management, 49, 156-161. http://dx.doi.org/10.2307/3801863

Kitchen, S. G., \& E. D. McArthur. (2007). Big and Black Sagebrush Landscapes. In: S. Hood \& M. Miller [EDS.] Fire ecology and management of the major ecosystems of southern Utah. Fort Collins, CO: US Department of Agriculture, Forest Service, Rocky Mountain Research Station. General Technical Report RMRS-GTR-202. p. 73-95.

Klepper, M. R., E. T. Ruppel, \& V. L. Freeman. (1971). Geology and mineral deposits, east flank of the Elkhorn Mountains, Broadwater County, Montana. Geological survey professional paper 665 .

Klinka, K., J. Worrall, L. Skoda \& P. Varga. (2000). Distribution and Synopsis of Ecological and Silvical Characteristics of Tree Species of British Columbia. Coquitlam, BC. Canadian Cartographics Ltd. 180p.

Knick, S. T., D. S. Dobkin, J. T. Rotenberry, M. A. Schroeder. W. M. Vander Haegen \& C. van Riper III. (2003). Teetering on the edge or too late? Conservation and research issues for avifauna of sagebrush habitats. The Condor 105, 611-634. http://dx.doi.org/10.1650/7329

Knight, D. H. (1994). Escarpments and foothill transition. In: D. H. Knight. Mountains and plains: the ecology of Wyoming's landscapes. New Haven, CT: Yale University Press. p. 133152.

Kufeld, R. C. (1973). Foods eaten by the Rocky Mountain elk. Journal of Range Management, 26, 106-113. http://dx.doi.org/10.2307/3896463

Kufeld, R. C., O. C. Wallmo \& C. Feddema. (1973). Foods of the Rocky Mountain mule deer. Fort Collins, CO: US Department of Agriculture, Forest Service, Rocky Mountain Forest and Range Experiment Station. Research Paper RM-111.31p.

Lesica, P., S. V. Cooper, \& G. Kudray. (2007). Recovery of big sagebrush following fire in southwest Montana. Rangeland Ecology and Management, 60, 261-269. http://dx.doi.org/10.2111/1551-5028(2007)60[261:ROBSFF]2.0.CO;2

MacCracken, J. G., \& R. M. Hansen. (1981). Diets of domestic sheep and other large herbivores in Southcentral Colorado. Journal of Range Management, 34, 242-243. http://dx.doi.org/10.2307/3898054

Miller, R. F., \& J. A. Rose. (1999). Fire history and western juniper encroachment in sagebrush steppe. Journal of Range Management, 52, 550-559. http://dx.doi.org/10.2307/4003623

Miller, R. F., T. J. Svejcar, \& J. A. Rose. (2000). Impacts of western juniper on plant community composition and structure. Journal of Range Management, 53, 574-585. http://dx.doi.org/10.2307/4003150 
Miller, R. F., R. J. Tausch, E. D. McArthur, D. D. Johnson, \& S. C. Sanderson. (2008). Age structure and expansion of pinon-juniper woodlands: a regional perspective in the intermountain west. Fort Collins, CO: US Department of Agriculture, Forest Service, Rocky Mountain Research Station. Research Paper RMRS-RP-69. 13p.

Miller, R.F. \& P.E. Wigand. (1994). Holocene changes in semiarid pinyon-juniper woodlands: response to climate, fire, and human activities in the US Great Basin. BioScience, 44, 465-474. http://dx.doi.org/10.2307/1312298

Montagne, C., L.C. Munn, G.A. Nielsen, J.W. Rogers, \& H.E. Hunter. (1982). Soils of Montana. Montana Agricultural Experiment Station. Montana State University and USDA Soil Conservation Service. Bulletin 744.

Montagne, C. (2009). LRES201. Soil Resource Lab Manual. Land Resources and Environmental Science Department. MSU. Soil Survey Division Staff. 1993. Soil survey manual. Soil Conservation Service. U.S. Department of Agriculture Handbook 18.

Mueggler, W. F. \& W. L. Stewart. (1980). Grassland and shrubland habitat types of Western Montana. Ogden, UT: US Department of Agriculture, Forest Service, Intermountain Forest and Range Experiment Station. General Technical Report INT-66. 154p.

Mueller, R. C., C. M. Scudder, M. E. Porter, R. T. Trotter III, C. A. Gehring, \& T. G. Whitham. (2005). Differential tree mortality in response to severe drought: evidence for long-term vegetation shifts. Journal of Ecology, 95, 1085-1093. http://dx.doi.org/10.1111/j.13652745.2005.01042.x

Noss, R. F., E. T. LaRoe, \& J.M. Scott. (1995). Endangered ecosystems of the United States: A preliminary assessment of loss and degradation. Washington, DC, US Department of the Interior. Biological Report 28.

Romme, W. H., C. D. Allen, J. D. Bailey, W. L. Baker, B. T. Bestelmeyer, P. M. Brown, K. S. Eisenhart, M. L. Floyd, D. W. Huffman, B. F. Jacobs, R. F. Miller, E. H. Muldavin, T. W. Swetnam, R. J. Tausch \& P. J. Weisberg. (2009). Historical and modern disturbance regimes, stand structures, and landscape dynamics in piñon-juniper vegetation of the western United States. Rangeland Ecology and Management, 62, 203-222. http://dx.doi.org/10.2111/08-188R1.1

Rowland, M. M., L. H. Suring, R. J. Tausch. S. Geer, \& M. J. Wisdom. (2008). Characteristics of western juniper encroachment into sagebrush communities in central Oregon. La Grande, OR: US Department of Agriculture, Forest Service, Forestry and Range Sciences Laboratory. 23p.

Sherich, K., A. Pocewitz, \& P. Morgan. (2007). Canopy characteristics and growth rates of ponderosa pine and Douglas-fir at long-established forest edges. Canadian Journal of Forest Research, 37, 2096-2105. http://dx.doi.org/10.1139/X07-105

Sindelar, B. W. (1971). Douglas-fir invasion of Western Montana grasslands. [Ph.D. Dissertation], University of Montana, Missoula, USA.

Smedes, H. W., M. R. Klepper, \& R. I. Tilling. (1968). Boulder Batholith: A description of geology and road log. Geological Society of America. Rocky Mountain Section, Bozeman Montana. 
Strand, E. K., A. M. S. Smith, S. C. Bunting, L. A. Vierling, D. B. Hann \& P. E. Gessler. (2006). Wavelet estimation of plant spatial patterns in multitemporal aerial photography. International Journal of Remote Sensing, 27, 2049-2054. http://dx.doi.org/10.1080/01431160500444764

Sudworth, G. B. (1915). Cypress and juniper trees of the Rocky Mountain region. Washington, DC: US Department of Agriculture. Bulletin 207. http://dx.doi.org/10.5962/bhl.title.64861

United States Department of Agriculture [USDA]. (1987). Deerlodge National Plan. USDA. Forest Service Deerlodge National Forest Pg.II-10.

USDA, NRCS (a). (2010). Psuedotsuga menziesii (Mirb.) Franco. Retrieved from http://plants.usda.gov/java/profile?symbol=psme.

USDA, NRCS (b). (2010). Web Soil Survey. Retrieved from http://websoilsurvey.nrcs.usda.gov/app/WebSoilSurvey.aspx.

Wambolt, C. L., M. R. Frisina, S. J. Knapp, \& R. M. Frisina. (2006). Effect of method, site, and taxon on line-intercept estimates of sagebrush cover. Wildlife Society Bulletin, 34, 440-445. http://dx.doi.org/10.2193/0091-7648(2006)34[440:EOMSAT]2.0.CO;2

Welch, B. L. (2005). Big sagebrush: A sea fragmented into lakes, ponds, and puddles. Fort Collins, CO: US Department of Agriculture, Forest Service, Rocky Mountain Research Station. General Technical Report RMRS-GTR-144. 210p.

Western Regional Climate Center. Retrieved from http://www.wrcc.dri.edu/Climsum.html.

\section{Copyright Disclaimer}

Copyright for this article is retained by the author(s), with first publication rights granted to the journal.

This is an open-access article distributed under the terms and conditions of the Creative Commons Attribution license (http://creativecommons.org/licenses/by/3.0/). 